\title{
The Little Cinema of Malaysia
}

\author{
By Hassan Abd Muthalib \\ Spring 2007 Issue of KINEMA
}

\section{THE LITTLE CINEMA OF MALAYSIA: OUT WITH THE OLD, IN WITH THE NEW}

MALAYSIAN mainstream cinema is notable (!) for its emphasis on pure entertainment and nothing but. The films were also notable (until recently), for not reflecting the ethnic and cultural diversity of Malaysia in spite of the official promotion of the country internationally as Malaysia, Truly Asia. Dishing out cliched, stereotypical and antiquated narratives and characters, many of these films somehow attain box-office success, proof that they are popular with a certain segment of the cinema-going public. None of these films, however, have been invited to participate in international film festivals. The few alternative films that have surfaced from time to time (and have had international exposure), have never had a mass audience, and them have ever made back their initial investment.

This gloomy scenario, however, has not fazed the group dubbed The Little Cinema of Malaysia. Working in the digital video (DV) format, its filmmakers have made their presence felt with their iconoclastic filmmaking. Ever since the wave first began in 1999, there has been no stopping its forward surge. International recognition has been quick in coming and their works are now regularly in exhibition or in competition and winning many top prizes - at prestigious festivals around the world. But more importantly, they have broken with the conventions and traditions prevalent in the mainstream since 1933 when the first local film was made.

The Little Cinema is notable for its diversity not only in the makeup of its members (who come from all races), but also in the diversity of ideas, issues and narratives they bring to the screen. Most importantly, films were no longer only in the official lingua franca - Bahasa Malaysia - nor were they about the problems of only one race - the Malays. And no longer were non-Malays relegated to only being comedy relief as had been the norm. The members of The Little Cinema are forcefully expressing their innermost feelings about themselves, reflecting on their place and position in a multi-racial, multi-cultural and multi-religious postindependence Malaysia. The presence of The Little Cinema has given rise to a different kind of Malaysian cinema that is rapidly developing alongside what had been previously only Malay Cinema.

The Little Cinema had its beginnings arising from a scenario that was, in hindsight, a harbinger of the iconoclastic road that it would take. In 1981, Dr Mahathir Mohammad, the fourth Prime Minister of Malaysia assumed the leadership of the country and immediately initiated drastic new ways of thinking and doing things. This included the push for the use of digital technology in all areas of business and government, and in effect, neatly planted the seeds of The Little Cinema of Malaysia (Dr Anuar Nor Arai, film critic and writer, came up with the name to differentiate them from the mainstream filmmakers whose final output is in the $35 \mathrm{~mm}$ film format). Parallel with the rise of The Little Cinema was the entry of new directors into the mainstream. Some of them brought alternative styles of cinematic storytelling after having cut their teeth making commercials or telemovies. Some members of The Little Cinema have since made their way into the mainstream (or at least had screenings in E-cinemas), bringing with them a gritty realism never before seen in local cinema. But most conspicuously, they chose not to use the country's lingua franca in their films.

The Little Cinema of Malaysia's appearance on the scene, its rapid progress and subsequent recognition was not wholly due to its own members' efforts. Their rise needs to be considered in the context of many developments within the industry. Among them:

1. The beginnings of mainstream cinema in Malaysia (1930s to the 1970s).

2. The push for the use of digital technology in all areas of business, education and entertainment in the early 1980s.

3. The emergence of the first wave of alternative filmmakers in the early 1980s.

4. The setting up of the first film school in the late 1980s.

5. The proliferation of institutions of higher learning offering film, broadcasting, multimedia and animation 
in the late 1990s.

6. The production and screening of the first amateur DV feature film in 2000.

7. The easy availability of (pirated) VCD/DVD classic and auteur films.

8. The numerous outlets available for screening DV works within the country.

9. Accessibility for participation in international film festivals.

10. Funding for making films (within and outside the country).

11. The emergence of the second wave of alternative filmmakers and their entry into the mainstream.

12. The support of mainstream publications, both local and international, and of academia.

\section{Early Malaysian Cinema}

Malaysia and Singapore have a shared cinema history as both countries were once part of British Malaya. Singapore was where the Malay-language film industry started with the first feature, Leila Majnun (B.S. Rajhans, 1933). Both the producer and the director were, however, Indian nationals. The film's actors were all Malays, all of whom came from bangsawan (traditional Malay opera). They were not loath to abandon bangsawan after the Second World War and enter full-scale into films as it promised them a steadier and more lucrative income. Though the key players of the industry were Chinese, Indian, Filipinos and Europeans, cinema then was totally a Malay cinema. The films were a motley collection of tear-jerkers, melodrama, horror, comedy and romance that were treated in a classicist manner.

However, realist tendencies were evident in some of the films of P. Ramlee, M. Amin and Hussein Haniff but the melodramatic narratives continued to be maintained. A curious aspect of cinema then was the total absence of anti-colonial sentiments, in stark contrast to the literary and journalistic scene. Instead, criticism was levelled at the Malays themselves: at royalty, the rich and especially the ordinary man. Non-Malays usually appeared as comedy relief or as extras, playing leading roles in only two films, Seruan Merdeka (The Call to Independence - B. S. Rajhans, 1946), where for the first and only time on screen, Malays and Chinese fought the Japanese, and Selamat Tinggal Kekaseh-ku (Goodbye, My Love by L. Krishnan, 1955), the first film to depict inter-racial love. The first feature film to be made in Kuala Lumpur by the Malayan Film Unit was Abu Nawas (Cyril Randall, 1954). The film portrayed the communist insurgency but it only had limited screenings as all the communists were shown to be Chinese and the victims, Malays.

With the closure of the Shaw Brothers studios in 1968 and then the Cathay Organisation studios in 1972, the film scene shifted to Kuala Lumpur. However, the Shaw Brothers' studio in Kuala Lumpur did not fare well, finally closing in 1980. Many of the Malay independent producers who had set up shop would have ended up croppers had it not been for the success of the populist films of Deddy M. Borhan under his company, Sabah Films. As in Singapore, serious subjects were still not forthcoming - and as before, it was still a Malay cinema.

\section{The First New Wave}

The entry of Rahim Razali with Abang (Big Brother, 1981), signalled a change and for the first time, Malay films were more realistic in story and treatment, eschewing the superficiality and melodrama of the past. Two years earlier, the playwright, Syed Alwi, had made Tok Perak for television, based on his own stage play (a $16 \mathrm{~mm}$ film version was also made but it has never been shown publicly. It was Syed Alwi's one and only film). The foreground story was about a roadside medicine seller but its background story was about the gradual loss of spirituality in Malay society. Rahim Razali echoed the same theme in Abang, relating it to Malays who had succeeded in business but then began to succumb to greed. His Matinnya Seorang Patriot (Death of a Patriot, 1984), was about the negative aspects of mixing business with politics. Tsu-Feh Sofia (1986), was about religious deviation and the kafir mengkafir issue (Muslims accusing other Muslims of being infidels). It was also about a Chinese woman's desire to convert to Islam. It took a while for similar themes to be taken up by other filmmakers such as Shuhaimi Baba. She, too, spoke of religious deviation in Selubung (The Veiled, 1992), with sex and politics taking centre stage in Ringgit Ka Sorgga (Dollars to Heaven, 1994).

The lone filmmaker to make a postmodernist feature was Mansor Puteh with his Seman (The Lost Hero, 1987). The story was about the angst of capable (Malay) youths who were estranged from a (Malay) society which ignored their talents. With its "direct cinema" approach, it broke totally with the conventions of 
previous films but film distributors (and even filmmakers), were not ready for this style. Mansor Puteh's energies consequently led him to single-handedly organising the first ever Kuala Lumpur International Short Film Festival in Kuala Lumpur in 1992, followed by a second one in 1994. It was the first time local audiences had experienced seeing all manner of shorts from outside the country.

U-Wei Hajisaari burst onto the scene with Perempuan, Isteri dan...(Wife, Woman and..., 1992), igniting controversy with his depiction of Malay male and female sexuality and psyche. His television drama, Khaki Bakar (The Arsonist, 1993), though rejected by television stations, was deemed good enough to be screened in the Un Certain Regard category at the 1995 Cannes Film Festival and went on to be screened in Malaysian cinemas. Khaki Bakar was about a man who was upset at the world and whenever he was criticized, he would resort to burning the nearest barn.

U-Wei had only one theme in all his films and it was a continuous exploration of the Malay psyche, exploring some of their negative aspects. He took an objective stance and merely presented his thesis, leaving it to his audience to figure things out for themselves. Not so Hishamuddin Rais with his Dari Jemapoh ke Manchestee (From Jemapoh to Manchester, 1998). His was a call to Malay youths to break away and reject anything that was Malay. To him, that was the only way they could emancipate themselves and go on to higher things. Clearly, he was the most radical of the Malay filmmakers but just like the other alternative filmmakers, Hishamuddin Rais was only concerned with his own race.

\section{Training the Filmmakers}

The first wave of alternative filmmakers had studied film or theatre overseas. Inspired by this group, many young people (mostly Malay), were eager to be involved in the film industry. At this time, mass communications, broadcasting and a few film courses were already being taught in local colleges and universities. But the setting up of the first film school gave promise of the changes to come. The Malaysian Film Academy started operations in 1989 but it was only the third batch of graduating students in 1997 that began to make some headway in the industry. Some became actors, others cinematographers or writers. Some became directors but could not initiate the desired changes as the old school of film practitioners (who were not formally trained), were too entrenched in their outdated way of doing things. One of these graduates was to be involved in the making of the first DV feature that was to kick-start The Little Cinema.

With animation and multimedia becoming a big thing towards the end of the 1990s, it was full steam ahead for institutions of higher learning to also provide grounding in film and television production. Students were subsequently required to make a graduation film for their final year of study and some of these films were submitted to film festivals. A surprising outcome - and one that was to give an impetus to short film production - was when several of the films won international awards. These films were not only well-made technically but also had narratives that played with ideas - an important criteria for short film production.

Students and techno-savvy filmmakers today have many other sources for ideas and inspiration. Surfing the Web for information on filmmaking and filmmakers worldwide is a popular choice. Another (illegal) source is unconventional. Access to the classics of cinema, auteur movies as well as the latest festival films, comes from a steady supply of low cost, pirated VCDs and DVDs. Due to the demand, even the pirates have become knowledgeable about the auteurs of cinema such as Kurosawa, Verhoeven, Fellini and Bergman (one DV filmmaker remarked that the video pirates were even willing to fund alternative filmmakers)! The bonus material found in DVDs is a useful source of reference to understand production methods and approaches.

\section{The Second Wave of Alternative Filmmakers}

With the millennium came the proverbial light at the end of the tunnel. The second wave of alternative filmmakers were a diverse group, both in ethnicity and training. It fell to them to reflect, for the first time, the ethnic and cultural diversity of the country. Teck Tan, a film graduate just returned from Australia, was the first to foreground non-Malays with his inter-racial love story, Spinning Gasing (2001). Though superficial in treatment, it was a brave effort - and in hindsight, signalled the changes that were to follow. Hardly two years later, the baton was taken up by Yasmin Ahmad with her debut feature, Sepet (Slant-eyed, 2003), another inter-racial love story. Like Teck Tan's film, Sepet was cross-over cinema - trying to reach out to a wider audience but still maintaining an authorial voice. She mixed newcomers with established actors and liberally mixed Bahasa Malaysia with English and Chinese. 
Her story began with a Chinese song and went on to an Italian opera song, signifying firstly, that the story was related to the problems faced by the Chinese community in Malaysia but that in the final analysis, their fate was still uncertain. She became the first Malay filmmaker to "speak" on behalf of the non-Malays. But what made certain sectors of the Malay community uncomfortable was her subtle criticism of Malay special rights. Inevitably, she became the target of spiteful attacks (led by an entertainment writer from a Malay daily), that even extended into her second feature, Gubra (Panicky, 2005). The subjects, themes and articulations of Spinning Gasing, Sepet and Gubra had not gone unnoticed by The Little Cinema. Certain elements (especially those found in Yasmin Ahmad's films), were to inspire some of them and then be taken up in their own films.

\section{The Beginning of the Revolution}

DV feature film production first began with two works by graduates of the Malaysian Film Academy: Osman Ali made Bukak Api (Open Fire) in 1999. He was to become instrumental in providing opportunities for some formally-trained and also DV filmmakers to enter the mainstream when he became Head of Drama at a local TV station. Bukak Api foregrounded prostitutes and transvestites, showing a side of Kuala Lumpur never before seen. Though made specifically to educate sex workers, the film became a hit due to its use of dramatic narrative and gritty style and has since been shown in festivals around the world. Belum Lagi Kiamat (Not Yet the End of the World, 1999) followed, made by Santosh Kesavan but it fell to Amir Muhammad with his digital feature, Lips to Lips (2000), to begin the revolution that would give rise to The Little Cinema of Malaysia. With some professional help, including technical and creative assistance from Isazaly Md Isa, another graduate of the Malaysian Film Academy, Amir Muhammad made a tongue-incheek feature utilising a multi-racial-lingual cast comprised of local thespians. Creatively circumventing the censorship board's regulations, the film was screened semi-publicly as multi-media theatre and soon started to surface in international film festivals.

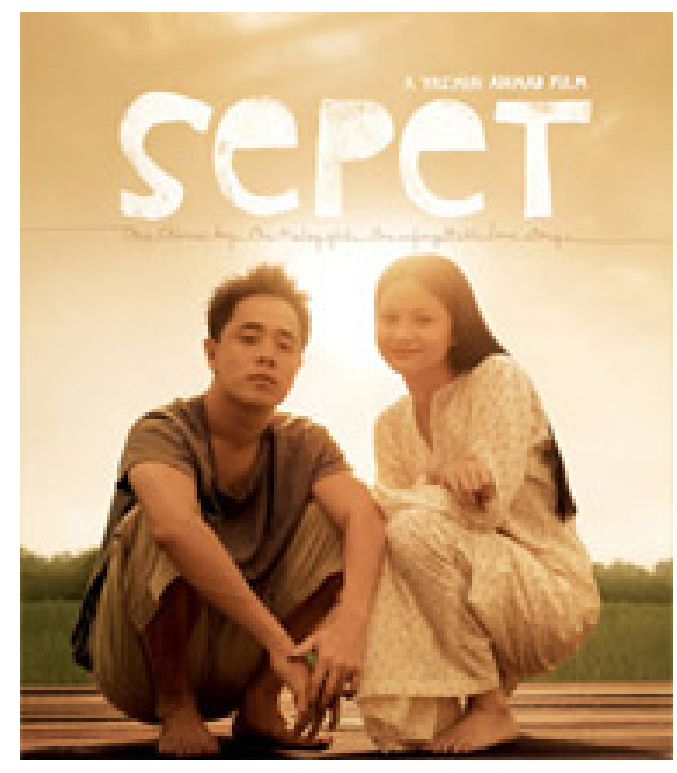

Figure 1: Sepet

This success caught the imagination of many who had access to (low cost) DV technology, including students who were in the process of making digital shorts for their final year in colleges and universities. The floodgates were opened and there was no stopping the tidal wave of DV filmmakers that followed, among them: James Lee (Snipers, Ah Beng Strikes Back, Room to Let and The Beautiful Washing Machine), Deepak Kumaran Menon (Chemman Chaalai / The Gravel Road, and Chalanggai / Dancing Bells), Ho Yuhang (Min and Sanctuary), Tan Chui Mui (A Tree in Tanjong Malim, Company of Mushrooms and Love Conquers All), Nam Ron (Gedebe / Gangsters), Bjarne Wong (Legend of the Red Curse and Possessed), Premnath Pillai (Uyir / The Soul) and Shanmugham Karuppannan (Sweet Dreams). Amir Muhammad himself went on to make innovative documentaries (The Big Durian, The Year of Living Vicariously, The Last Communist and 
Apa Khabar Orang Kampong? / Village People Radio Show). His The Big Durian became the first local film to be selected for the 2005 Sundance Film Festival. Other international achievers are James Lee with The Beautiful Washing Machine, a major win in Bangkok; Ho Yuhang, picked by First Cuts of Hong Kong to make Rain Dogs, and Tan Chu Mui who was awarded prestigious prizes in Pusan and Rotterdam for her Love Conquers All, which led to her being offered the $14^{\text {th }}$ Cinefondation Cannes Residency this year.

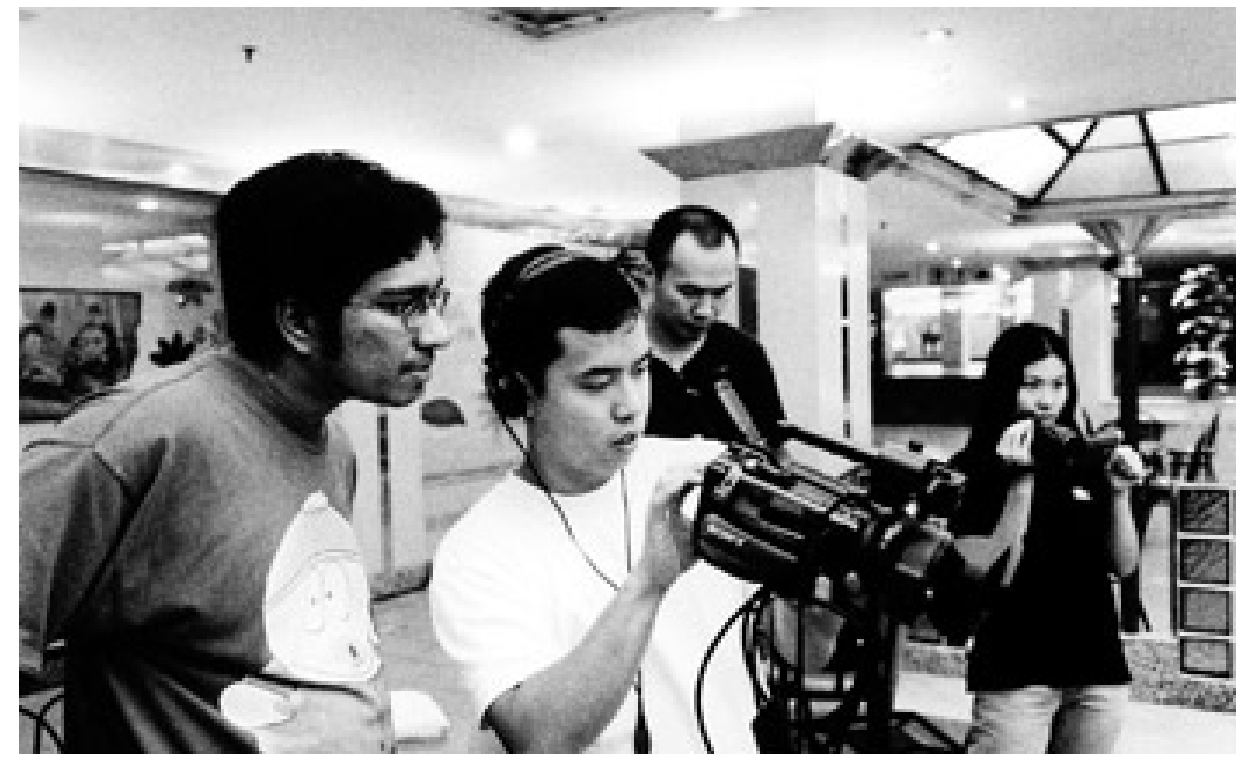

Figure 2: From l. to r.: Amir Muhammad, Woo Ming Jin, James Lee and Tan Chui Mui

\section{Competitions, Screenings and Funding Facilities}

The Film Club of Malaysia became the earliest and staunchest supporter of The Little Cinema by having a continuous showcase of their works at the HELP University College Thearette in Kuala Lumpur. The Club, through its President, Wong Tuck Cheong, also played a prominent role in exposing these works to international film festival curators who stopped by on their procurement trips. An organization called Khaki Kino initiated monthly film screenings at the University of Malaya that also included DV features. A number of shorts and features are now regularly screening on ASTRO, the satellite TV station. Cinema chains began to install digital screening equipment and as a result, a number of DV features were screened commercially. Ironically, these films are considered ?international films' as they are not in the national language (Bahasa Malaysia). Neither are they eligible for the entertainment tax rebate granted to local films because the relevant FINAS Act (passed by Parliament in 1981) stipulates that a Malaysian film must be in the national language. So far, there are no indications that this Act will be amended.

Local funding began to be provided by the Multimedia Development Corporation (MDeC). Beginning with grants for students to make short films, they creatively bent the rules to give lecturers and professionals opportunities to make use of the grants as long as they had students on the productions. FINAS, too, came up with small grants but it was money from Holland's Hubert Bals Fund, the New York-based Global Film Initiative, the Locarno Film Festival and Berlinale, as well as cash awards from films in competitions overseas that allowed DV filmmakers to continue making their films on a more professional level. ASTRO initiated competitions for the making of Chinese and Indian films for later screenings on its language-based channels. Corporations like Nokia and BMW, and even the Goethe Institute have also gotten into the act by offering competitive cash prizes. The annual Freedom Film Festival steered young filmmakers towards making social documentaries. The annual Malaysia Video Awards gave recognition to both established as well as new filmmakers. FINAS conducted student film competitions every year at different universities and colleges. Recently, the Information Ministry organized a student short film competition with cash prizes awarded to the winners. Even the Malaysian Film Festival has a category for short films in both the narrative and documentary category. 
The second wave of alternative filmmakers was more fortunate than the first. Mainstream production houses began to have faith in new talents. Many of them entered the arena, among them: Yasmin Ahmad, Bernard Chauly, Osman Ali, Woo Ming Jin, Dain Said, Santosh Kesavan and C Kumaresan. Amir Muhammad is the first from The Little Cinema to be entrusted with a cinema feature and is in the final stages of completing Susuk (The Charm). With many of these filmmakers also teaching film part-time, students receive the right guidance and also gain valuable experience working with them on professional projects. Unlike the mainstream cinema practitioners, these alternative filmmakers and members of The Little Cinema interact very well with each other, frequently helping out with each other's productions. Yasmin Ahmad (Executive Director of Leo Burnett Malaysia), has not only helped many in The Little Cinema by funding their shorts, she has also served as executive producer and even acted in a few features and shorts. For Tan Chui Mui's award-winning Love Conquers All, Amir Muhammad was the producer, James Lee, the cinematographer, and Ho Yuhang, the editor. Mui was producer for Deepak Kumaran Menon's Chemman Chaalai. Bernard Chauly and Amir Muhammad further help out as curators for the bi-annual screenings of works of The Little Cinema for the Film Club of Malaysia.

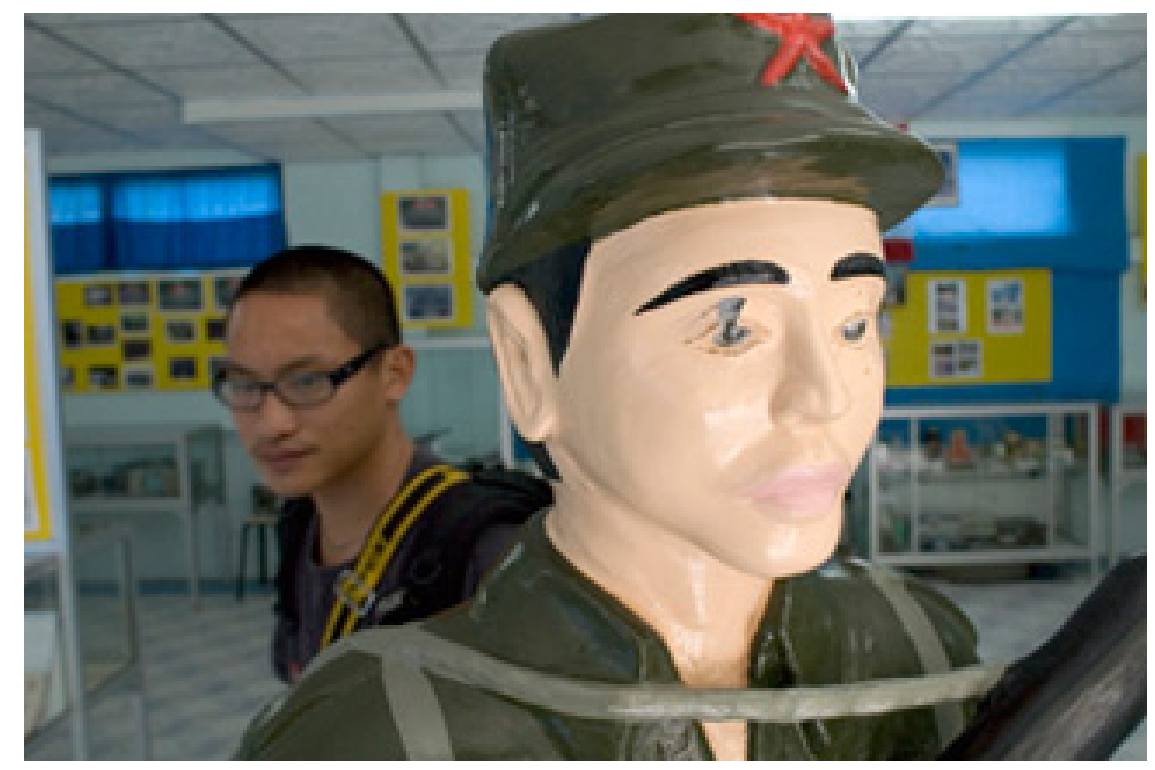

Figure 3: Last Communist by Amir Muhammad

A number of mainstream newspapers have also supported The Little Cinema in their writings, further encouraging new filmmakers. Mingguan Malaysia, a Malay weekly, devoted a column called Sinema Baru (New Cinema) to the developments in The Little Cinema. Many local and international magazines and websites regularly carry reviews of both the films of The Little Cinema and the alternative filmmakers. A number of university students' theses document and analyse their works. Academic conferences on Southeast Asian cinema are now actively featuring papers on them.

\section{The Future}

2005 was definitely the year of The Little Cinema of Malaysia. It was a film tsunami of sorts when seven features and eight shorts were chosen for the 34-year old Rotterdam Film Festival, among them: Buai Laju-laju (U-Wei Hajisaari, the only 35mm feature), The Beautiful Washing Machine and Goodbye to Love (both by James Lee), The Gravel Road and Wind Chimes (both by Deepak Kumaran Menon), Sanctuary (Ho Yuhang), Tokyo Magic Hour (Amir Muhammad), Visits: A Hungry Ghost Anthology (Ho Yuhang / Low Ngai Yuen / James Lee/ Ng Tian Hann), The Year of Living Vicariously (Amir Muhammad), Life Is Elsewhere (Kok Kai Foong), Love For Dogs (Woo Ming Jin), Out Of The Closet (Chi Too), Red Drawing (Margaret Bong), A Tree in Tg Malim (Tan Chui Mui), and Wanita Kosmos (Diffan Sina). This year, Rotterdam showcases James Lee's Before We Fall in Love Again, Yasmin Ahmad's Gubra, Ming Jin's The Elephant and the Sea, Deepak Kumaran Menon's Chalanggai and five shorts by Liew Seng Tatt, 
Sanjay Perumal and Kok Siew Wai. Tan won the Tiger Award for Love Conquers All and Menon got a Special Mention for Challangai. Some of these films are also in the $57^{\text {th }}$ Berlin International Film Festival (2007) resulting in Yasmin Ahmad's latest feature, Mukhsin, picking up two prizes; the Grand Prize of the Generation International Jury and Spetial Mention from the Generation Kplus Jury.

Changes were also seen in the mainstream. In 2006, two non-Bahasa Malaysia language films were entered for the first time in the Malaysian Film Festival: the Tamil film, Ethirkaalam (The Future, C. Kumaresan) and the Chinese-language, The Third Generation, directed by L. Hor). The latter film even managed to clinch three awards Innovativeness still lay with The Little Cinema even though dark clouds threatened to engulf it. Amir Muhammad's Lelaki Komunis Terakhir (The Last Communist, 2006), passed by the Censors and slated for screening in E-cinemas, ended up being banned after an assault through unethical journalism (by the same over-zealous journalist who had earlier blasted Yasmin Ahmad and her film, Gubra, for supposedly "tarnishing Malaysian customs and morals"). The controversy that erupted was further proof of the increasing chauvinism among certain quarters in the country to the rise of non-Bahasa Malaysia films.

What is significant is the discernible movement that is taking shape in Malaysian cinema involving both the alternative filmmakers and The Little Cinema. Yasmin Ahmad's subtle criticism of Malay special rights in Sepet was echoed in Arivind Abraham's S'kali (Altogether, 2006), a DV feature about five young friends of different races who go everywhere together. One of them has difficulties in finding a place locally to further his studies and reluctantly makes plans to go overseas. Ho Yuhang, James Lee and Tan Chui Mui speak of Chinese youths who are facing an identity crisis in their own country. The landscape (both physical and mental), that these filmmakers depict is one that is bleak, offering no solace or sanctuary, raising uncomfortable questions about the uncertain future of youths like them in a country that they have called their own.

The films of The Little Cinema of Malaysia are, in effect, saying that the outdated narratives and styles of mainstream cinema are out and must be replaced with the new. This generation of filmmakers (together with the second wave of alternative filmmakers), is set to take Malaysian cinema into new territory but it is still the audience that will ultimately decide whether a transformation will ever take place. Though film literacy is on the rise, the audience for the films of The Little Cinema is one that is still a niche. But with its increasing international successes, the filmmakers of The Little Cinema have initiated a movement that cannot be ignored. Their cinema may ultimately turn out to be the real cinema - and one that truly reflects the social reality and diversity of Malaysia.

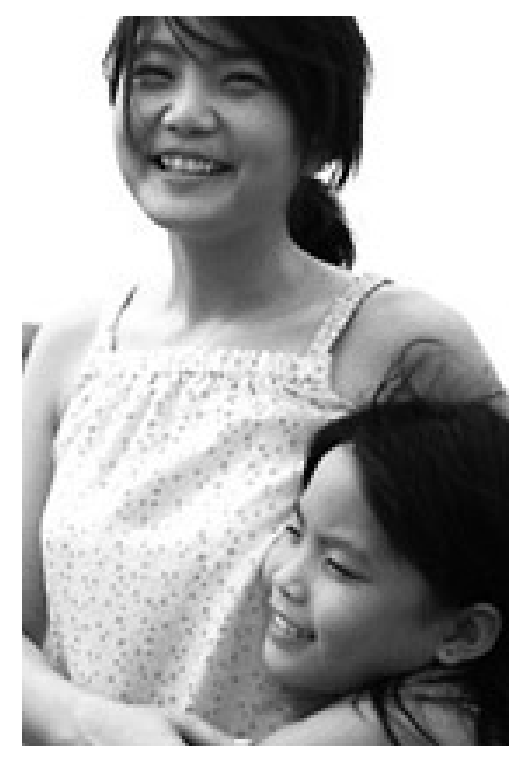

Figure 4: From Love Conquers All by Tan Chui Mui 


\section{Notes}

(This is an edited version of a paper presented at the Regional Seminar on Southeast Asian Cinema held at Ngee Ann Polytechnic, Singapore from 8-10 February 2007)

\section{References}

Khoo, Gaik Cheng. "Just-Do-It-(Yourself): Independent Filmmaking in Malaysia." New Southeast Asian Cinemas: Where Big Budget Meets No Budget Conference. Asia Research Institute Conference, Singapore, May 3-4, 2004.

Hassan Abd Muthalib. "Voices of Malaysian Cinema." Posted on malaysian-cinema@yahoo groups on 27 June, 2005.

\section{Author Information}

Hassan Abd MUTHALIB is an award-winning filmmaker who teaches at some of the top design, animation and film colleges in Malaysia. He is also president of the Animation Society of Malaysia. He co-authored the Malaysian entry for Being and Becoming: The Cinemas of Asia and is presently compiling material for books on Malaysian animation and cinema. 